\title{
Impact on Green Purchase Intention by Brand Equity Dimension
}

\author{
Gatot Iwan Kurniawan $^{\text {a, } 1}$, Ivan Diryana ${ }^{\text {a, } 2}$ \\ ${ }^{a}$ STIE Ekuitas, Jl.P.H.H. Mustofa No. 31 Bandung, 40124, Indonesia \\ ${ }^{1}$ gatot.iwan@ekuitas.ac.id, ${ }^{2}$ ivan.diryana@ekuitas.ac.id
}

\begin{abstract}
Green products have a better value to offer compare to conventional products, it give the consumer a chance to contribute to the environment. While other research shows that customer are willing to buy products with better value but that's not what happen to green products. Also people are reluctant to buy green product even though they have the awareness and knowledge about the environment condition because green products are perceived to be expensive. This paper is trying to give a different approach by connecting Brand Equity to Green Purchase Intention because expensive products with a strong brand will be easier to sell. Also this research is trying to explain what is the most influential dimension of Brand Equity that contribute to Green Purchase Intention.
\end{abstract}

Keyword: Green Marketing, Brand Equity, Purchase Intention.

\section{INTRODUCTION}

Today humanity face a much grater challenge, that is climate change. Like secretary-general Ban Ki-Moon said that the human environmental and financial cost of climate change is fast becoming unbearable. Sevil (2011) stated that factors such as population growth, global warming, threats to our future also the threat of running out of natural resources has lead to the development of green marketing concept. This concept perhaps is one of many ways to change the environment condition. If more and more people buy more environmental friendly product then perhaps we can stand a chance in battle agains the climate change or other environmental disaster.

However, according to Joel Makower (2011), environmental friendly product are less attractive to the market. Gan, Wee, Ozanne, Kao, (2008) found that on each of the product category, green product only able to gain no more than $1 \%$ of the market share. He said that one of the reason why green product are less attractive is because customer not willing to pay more for the green product compare to the same conventional product. Awareness and knowledge of today environment condition do not mean they will behave in an ecological manner (Pickett-Baker and Ozuki, 2008). In this era of information technology where people can access any information just by using their cell phone it is unlikely to find a person who do not know about climate change or any other environmental issue that we are facing right now. It is not much different in Indonesia, from our preliminary study in Bandung $82 \%$ of the respondent feel worry about the environmental, $84 \%$ of the respondent have knowledge about the important of environmental protection and $82 \%$ said that they care about environmental preservation. But when we ask about their willingness to more for green product only $42 \%$ said that they are gladly to do that.

Many of researcher trying to find the gap between purchase intention of green product and environmental awareness and knowledge. On this paper we try to that from another point of view by using brand equity as the antecedent of green purchase intention as clearly stated above that people reluctant to buy green product because of the price but products with high brand equity can be sold higher, or in other word customers are willing to pay more (Veloutsou, Christodoulides dan Chernatony, 2013; Yoo, Donthu, Lee. 2000). Thus in this paper we study the effect of brand equity dimension on purchase intention of green product in order to have a better understanding of how those dimension works on green purchase intention.

Objective of study

The objective of study is to investigate a relationship brand equity dimension with green purchase intention.

A. Green Marketing.

\section{LITERATURE REVIEW}

According to American Marketing Association (2014) there are three definition of green marketing, retailing definition, social marketing definition and environments definition. The retailing definition is the marketing of products that are presumed to be environmentally safe. From social marketing, green marketing defined as the development and marketing of products designed to minimize negative effects on the physical environment or to improve its quality. Last one is the environment definition where green marketing is defined as the efforts by organizations to produce, promote, package, and reclaim products in a manner that is sensitive or responsive to ecological concerns.

Other defintion is from Chen and Chang (2012), green marketing is activities undertaken by the company where the company is concerned about environmental issues by providing products or services that affect both the environment to create customer satisfaction and community. Thus we can see green marketing as the set of activities from production to marketing of a product which is believe to be environmental friendly. 


\section{B. Brand Equity}

David A. Aaker (1991) defined as the set of brand asset and liabilities linked to the brand, its name and symbols, that add value to, or subtract value from, a product or service. These assets include brand loyalty, brand awareness, perceived quality and brand associations. It is the consumers' perception of the overall superiority of a product carrying that brand name when compared to other brands.

- Brand loyalty, this dimensions create value by reducing costs and increasing sales promotion. Loyal consumers always want products with the brand, they want the product always available and also would recommend the product to others. Managing loyal consumers are not costly compared to attracting new customers despite small switch cost. Competitors will be difficult to communicate with consumer who already loyal to another product because the consumer has a low motivation to study alternative products .

- Brand Awareness, awareness of a brand is a feeling of familiarity to the brand and the substance of the message and commitment. Well-known brands are considered reliable and have good quality . Awareness of the brand even further influence the selection of products in the minds of consumers about the products, including the consideration by the consumer before the consumer make a purchase.

- Perceived Quality, good quality perceived by consumers will encourage consumers to buy the product. A brand will be associated with the perception of overall quality by consumers and should not be based on a detailed knowledge of the product. Qualities associated by brand can be a strong differentiation factor when compared to other products and also in product positioning .

- Brand association, can refer to people, context, lifestyle, or personality where all these things can affect the experience when using services or products and also helps when processing and retrieving information in certain circumstances. Identical products can provide different effects for different associated brand. Brand associations may be a critical factor during differentiation and positioning because it can encourage potential prospects who are looking for products that have the physical feature or emotional associations.

Yoo, B., Donthu, N., Lee, S. (2000) define brand equity as the difference when consumers choose a brand with products that are not branded where these products have high levels of the same features. High brand equity means that the consumer has a positive and strong associations to the brand, have a good perception of the quality and loyal to the brand. According Christodoulides and Chernatony (2010) concept of brand equity can be divided into two perspectives which is brand equity from the perspective of other financial and brand equity from a consumer standpoint. Brand equity from the perspective of consumers according to Christodoulides and Chernatony (2010) is a series of perceptions, behaviors, knowledge and attitudes to the consumer that can increase the utility and allows a brand gain more sales volume or more margins when compared with product that do not have a brand. Vazquez, Río and Iglesias (2002) says that the overall brand equity is a utility that is associated by the consumers into the use and consumption of the brands including associations to express both the utility function and symbolic. The study shows the four dimensions of brand utility is functional utility of the product, symbolic utility of the product, the functional utility of the brand, as well as utilities symbolic of the brand.

Keller (2013) proposed the concept of customer-based brand equity, in which Brand Equity seen through the perspective of the consumer. According to Keller (2013) brand equity is a differential effect of brand knowledge that affect consumer response to the brand marketing efforts where knowledge of brands established through brand image and brand awareness. According to $\mathrm{Yu}$-Shan Chen (2010) green brand equity, is a set of assets and liabilities of the environment commitment and environmental concerns associated with the brand, brand names and symbols that can increase or decrease the value in a product or service. Environmentally friendly brand equity is as good as what an eco-friendly brand is perceived by consumers and how much the value of environmental principles can be added value for the brand, depending on the product image as a brand that cares for the environment, customer satisfaction and trust are built by product that, as a brand that cares and is not harmful to the environment.

From the above literature we can see that brand equity is consumer perceptions of the brand related to the value added by the brand on a product so that consumers have a strong positive associations to the brand further more brand equity is rely on brand loyalty, brand association, brand awareness, and perception of quality .

\section{Purchase Intention}

In general purchase intention will transcend to actual purchase if people have strong intention toward buying the product (Ajzen, 1991). Thus customer will likely to buy green product if they have strong intention to purchase. According to Keller (2013) purchase intention is an important factor for consumers during considering and evaluating of certain product. Ghosh (1990) said that purchase intention can be an effective tool to predict purchasing process. Customer will be driven by their 
intention to purchase and then decide to purchase the product in certain store.

According to Dodds, Monroe, and Grewal (1991), purchase intention is when customers whishing to buy products. Thus purchase intention can be use to measure the possibility of customer to buy a specific product. However according to Zeithaml (1988) purchase intention might be altered because of price, perceived quality and perceived value. This is what happen to green product, people are aware about the environment, they have the intention toward purchasing green product but price of the product alter their intention, thus building more awareness and educate people more are not the best answer. As long as the price is higher than the conventional products which give the same basic function, people are reluctant to buy it. But a lot of green product manufacturer find it hard to lower their price, logically green product must pass certain requirement and it will need extra process to validate the greenness by some validation organization, which will increase the production cost compare to conventional product.

\section{CONCEPTUAL FRAMEWORK}

There are many empirical studies shows that brand equity is the driver of the purchase intention (Ashill and Sinha, 2004; Chang and Liu, 2009). According to Aaker (1991), brand equity have a positive impact towards the consumers purchase intention. Aaker (1991) and Keller (2013), said that all the brand equity dimension which is brand loyalty, brand awareness, brand associations, and perceived quality, have a significant influence on the consumers purchase intention. Kotler, (2013) stated that powerful brand equity effects in customer purchase intention for one product over another.

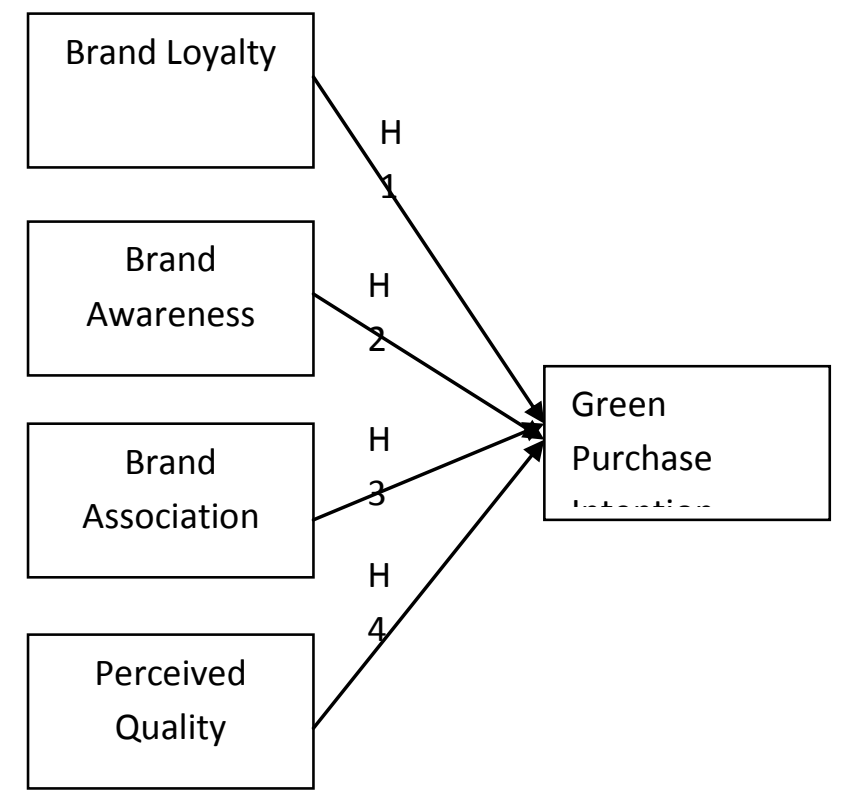

Fig. 1: Research Framework
H1. Brand Loyalty has a significant direct effect on purchase intention.

H2. Brand Awareness has a significant direct effect on purchase intention.

H3. Brand Association has a significant direct effect on purchase intention.

H4. Perceived Quality has a significant positive direct effect on purchase intention

Data and Methodology

We use The Body Shop customer as our respondent, since the company are well known as the environmental friendly company. Brand equity dimension from Aaker act as the independent variable, which can be measured from this statement.

Below are the items to measure brand loyalty:

- I will purchase products with the same brand again

- I will recommend the products with the brand to other people

Below are the items to measure brand awareness.

- I have ever heard about brand

- I know how product look like

Below are the items to measure brand association.

- The products features fulfill my needs

- The products fits with my lifestyle

Below are the items to measure to measure perceived quality

- $\quad$ Product have excellent performances

- The product features match with the promised ones

As for the dependant variable, Green Purchase Intention, can be measured with below statement.

- I will consider to purchase green product

- I would buy green products in order to save the environment

We conduct the survey in Bandung to those who have the experience using The Body Shop products. purposive sampling method is used since there is no information about the green product population in Bandung. Likert scale is use with five scale range. We collected 82 respondents who are match with the research requirement. The data then processes using partial least square method considering the 
total respondent that we can collect during this research, SmartPLS version 2 is use.

\section{Result}

By examining the loadings of respective factors on their respective latent constructs we can assessed individual factor reliability (Hulland, 1999). The higher loadings means that there is more shared variance between the construct and its measures than error variance. In this study we using criteria of 0.50 as recommended by Hulland (1999).

TABLE I

Outer Loadings

\section{Outer Loadings}

\begin{tabular}{|c|c|c|c|c|c|}
\hline \multirow[t]{2}{*}{ Mats } & \multicolumn{5}{|r|}{ Export te clophand } \\
\hline & Sland ksuocotion & Irond Auraeness & Brard loyalty & Green Purch zelintertion & PactivedQuaity \\
\hline BN & & 0835 & & & \\
\hline BA & & 089 & & & \\
\hline BASL & 9966 & & & & \\
\hline BLS2 & 0365 & & & & \\
\hline GPI & & & & $083 \pi$ & \\
\hline GFI & & & & 0875 & \\
\hline tod & & & 1909 & & \\
\hline 102 & & & LBS4 & & \\
\hline PQ1 & & & & & 0862 \\
\hline$P Q Q$ & & & & & $\cos 33$ \\
\hline
\end{tabular}

Reliability of each variable can assessed through Fornell and Larcker's (1981) measure of composite reliability, In addition to Cronbach's alpha. Composite reliability is preferred over Cronbach's alpha because it offers a better estimate of variance shared by the respective indicators also because Composite reliability uses the item loadings obtained (Hair, Black, Babin, Anderson and Tatham, 2006). In this research the composite factor reliability coefficients ranged from 0,869 to 0,903 which pass the standard of 0.70

\section{Composite Reliability}

Composite Reliability

\begin{tabular}{|c|c|c|}
\hline 模率 Composite Reliability & 国 Matrix & \\
\hline & Com & pposite Reliability \\
\hline Brand Association & & 0.903 \\
\hline Brand Awareness & & 0.876 \\
\hline Brand Loyalty & & 0.891 \\
\hline Green Purchase Intention & & 0.869 \\
\hline Perceived Quality & & 0.870 \\
\hline
\end{tabular}

TABLE III

Cronbach's Alpha Reliability of the Measure

\section{Cronbachs Alpha}

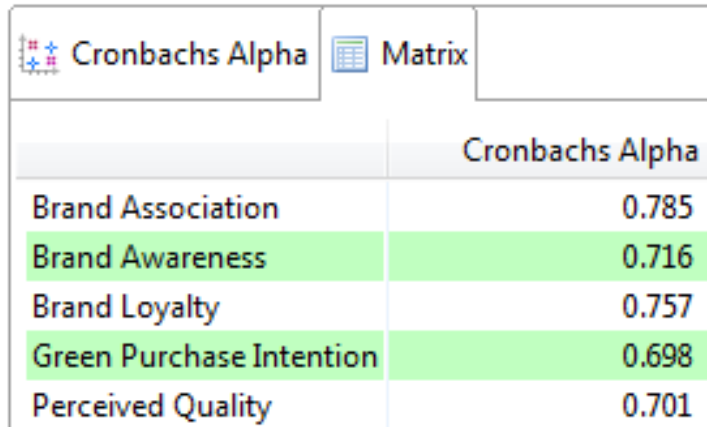

As for Cronbachs Alpha, only Green Purchase Intention that does not meet the requirement which has to be higher than 0,7. Nevertheless the Average Variance Extracted (AVE) is greater than 0,5 also the composite realiability is greater than 0,7 so we can continue with our calculation.

TABLE IV

Average Variants Extracted

\section{Average Variance Extracted (AVE)}

\begin{tabular}{|l|l|}
\hline 拱直 AVE & \\
\hline & AVE \\
\hline Brand Association & \\
\hline Brand Awareness & 0.823 \\
\hline Brand Loyalty & 0.779 \\
\hline Green Purchase Intention & 0.804 \\
\hline Perceived Quality & 0.768 \\
\hline
\end{tabular}

\section{Structural Model Analysis}

A bootstrapping procedure using 500 sub samples was performed to evaluate the statistical significance of each path coefficient. 
TABLE IV

Path Coefficients

\section{Path Coefficients}

\begin{tabular}{|c|c|c|c|c|c|c|c|c|}
\hline \multirow[t]{2}{*}{ 囯 Mean, STDEV, T-Values, P-Val... } & 圆 Confidence Intervals & \multicolumn{2}{|c|}{ Confidence Intervals Bias Cor... } & 罡 Samples & \multicolumn{2}{|c|}{ Export to clipboard: } & 蕆 $R$ & \multirow[b]{2}{*}{ PValues } \\
\hline & \multicolumn{2}{|c|}{ Original Sample (0) } & Sample Mean (M) & \multicolumn{2}{|c|}{ Standard Error (STERR) } & \multicolumn{2}{|c|}{ T Statistics (|0/STERR|) } & \\
\hline \multicolumn{2}{|c|}{ Brand Association -> Green Purchase Intention } & 0.269 & 0.266 & & 0.086 & & 3.128 & 0.002 \\
\hline \multicolumn{2}{|c|}{ Brand Awareness $->$ Green Purchase Intention } & 0.128 & 0.122 & & 0.081 & & 1.568 & 0.117 \\
\hline \multicolumn{2}{|c|}{ Brand Loyalty -> Green Purchase Intention } & 0.315 & 0.318 & & 0.128 & & 2.459 & 0.014 \\
\hline \multicolumn{2}{|c|}{ Perceived Quality -> Green Purchase Intention } & 0.268 & 0.272 & & 0.077 & & 3.469 & 0.001 \\
\hline
\end{tabular}

The relationship between Brand Awareness and Green Purchase Intention was insignificant with $\beta=0.128$ and $t=$ 1,568 (table value is 1.96 at 0.05 degree of freedom $>120$ ) indicating that the Brand Awareness has direct positive insignificant influence on the Green Purchase Intention. The rest of the dependant variables have positive significant influence on the Green Purchase Intention with $\beta=0.315$ and $t=2,459$ for Brand Loyalty, $B=0.269$ and $t=3,128$ for Brand Association, $\beta=0.268$ and $t=3,469$ for Perceived Quality.

As for path coefficients, the result from lower to higher score are Brand Awareness 0,128; Perceived Quality, 0,268; Brand Association 0,269; and Brand Loyalty 0,315. Thus from the path diagram below we can see the path coefficients, loading factors and the $\mathrm{R}$ square value which is 0,746 means that the fit explains $74,6 \%$ of the total variation in the data about the average.

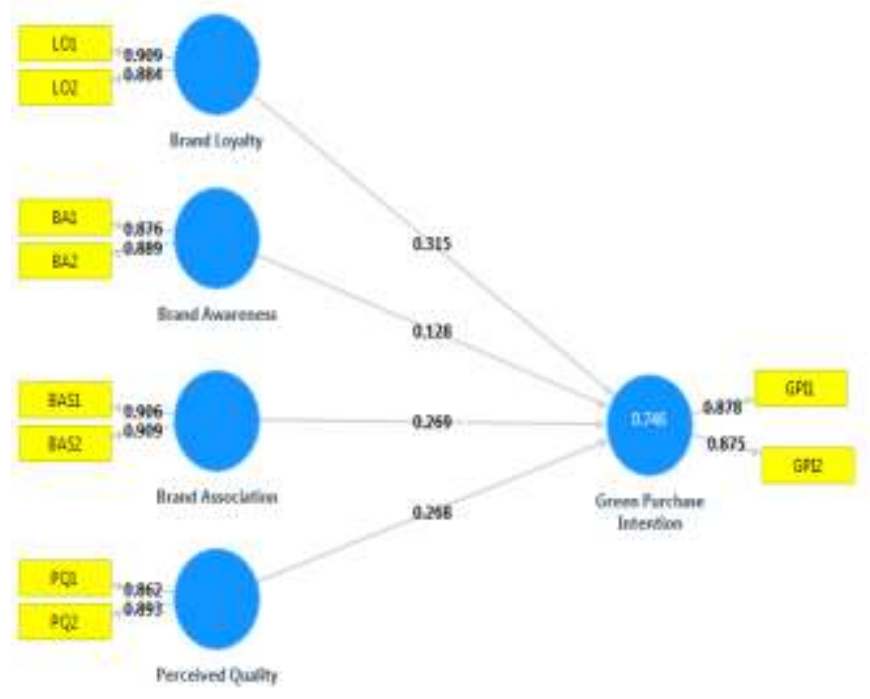

Fig.2 : Result from PLS Algorithm

\section{Conclusion}

The result shows that Brand Awareness have nothing to do with Green Purchase intention, most of the strategy to build brand awareness is using promotion but from this study it shows us that give it too much attention to promotion on any others way to increase brand awareness seems not a good and effective way in terms of building purchase intention. Customer do not feel the urge to remember the brand or can recall the brand immediately, perhaps because for green products knowing and remembering the function of the products toward the environment are more important.

The company also have to pay attention on how to build brand loyalty, brand association and perceived quality. It might be a good thing to incorporate buying and using green product as a lifestyle, educated the customer that this is a good lifestyle or associate the product with other things that able to motivate customer to grasp more green lifestyle. A study showed that $42 \%$ of people will not buy environmentally friendly products because they worry that the product does not functioning as a conventional product (Fowler, 2002). Another survey showed that as many as $61 \%$ of consumers believe if environmentally friendly products have lower effectiveness than products that are not environmentally friendly (GfK Custom Research North America, 2009). Perceived quality is one of the variable that must be considered by the company. From the study mention before there is a problem with perceived quality, company must take significant effort to built a good quality perception among the people. Do not ignore the quality of the product in order to pursue for greenness. Companies can improve the quality of their products in order to have a competitive advantage (Parasuraman, Zeithaml, Berry, 1988). Both practitioners and researchers should pay attention to both the perception of quality because it has a positive effect on the performance of marketing so that the current perception of the quality to be very important (Sweeney et al., 1999). 
This research give us a glimpse on how brand equity dimension can influence purchase intention, further research can be held by adding other variables that also know to have significant effect to purchase intention. Also a research with much larger respondent can be held in order to give a better insight.

\section{References}

Aaker, David. 1991. Managing Brand Equity: Capitalizing on the Value of Brand Name. Free Press. New York. Ajzen, I. (1991). "The theory of planned behavior". Organizational Behavior and Human Decision Processes, 50(2), 179-211.

Ashill, N. J., \& Sinha, A. (2004). "An exploratory study into the impact of components of brand equity and country of origin effects on purchase intention". Journal of AsiaPacific Business, 5(3), 27-43.

Chang, H. H. and Liu, Y. M. (2009). "The Impact of Brand Equity on Brand Preference and Purchase Intentions in the Service Industries". The Service Industries Journal, 29(12), 1687.

Chen, S. Y. \& Chang, S.C. (2012) Enhance green purchase intention: the roles of green perceived value, green perceived risk and green trust. Management Decision, 50, (3), 502-520.

Chen, Y.-S. (2010) "The drivers of green brand equity: green brand image, green satisfaction, and green trust". Journal of Business Ethics, 93, (2), 307-19.

Christodoulides, G. and de Chernatony , L. (2010) "Consumer-based brand equity conceptualisation and measurement: a literature review". International Journal of Market Research, 52 (1). pp. 43-66

Dodds, William B., Kent B. Monroe, and Dhruv Grewal. (1991). "Effects of Price, Brand and Store Information on Buyers' Product Evaluations, " Journal of Marketing Research. 28 (August): 307319.

Fornell, C., and Larcker, D. F. 1981. "Evaluating Structural Equation Models with Unobservable Variables and Measurement Error,' Journal of Marketing Research (18:1), pp. $39-50$

Fowler, G.A. (2002) "Green sales pitch isn't moving many products". Wall Street Journal, (6) B1 dan B4.

Gan, Christopher ; Wee, Han Yen; Ozanne, Lucie and Kao, TzuHui (2008). Consumers' purchasing behavior towards green products in New Zealand, Innovative Marketing, Volume 4, Issue 1.

Gfk Custom Research North America (2009), Americans Reach Environmental Turning Point.. Companies Need to Catch Up According to Gfk Roper Green Gauge(R). www.greenbusinesscoalition.org/articles/2-americansreach-environmental-turning-point-companies-need-tocatch-up-according-to-gfk-roper-green-gauge-r-study.pdf

Ghosh, A. (1990), Retail Management, 2nd ed., The Dryden Press, Chicago, IL

Hair, J., Black, W., Babin, B., Anderson, R., \& Tatham, R. (2006). Multivariate data analysis (6th ed.). Uppersaddle River, N.J.: Pearson Prentice Hall.

Hulland, J. (1999)."Use of partial least squares (PLS) in strategic management research: a review of four recent studies". Strategic Management Journal, 20(2), 195-204

JC Sweeney, GN Soutar, LW Johnson (1999), "The role of perceived risk in the quality-value relationship: a study in a retail environment", Journal of retailing, 1999 -Volume 75, Issue 1, Spring, p. 77-105

Keller, Kevin Lane. (2013) "Strategic Brand Management: Building, Measuring, and Managing Brand Equity" Pearson fourth edition

Makower, Joel (2011) Green Marketing Is Over. Let's Move On.

http://www.greenbiz.com/blog/2011/05/16/greenmarketing-over-lets-move?page $=$ full

Parasuraman, A., Zeithaml V. A., Berry L. L., Servqual: "A multiple-item scale for measuring consumer perceptions of service quality", Journal of Retailing, Vol. 64, No. 1, pp.1240, 1988.

Pickett-Baker, Josephine and Ozaki Ritsuko, (2008) "Pro-environmental products: marketing influence on consumer purchase decision", Journal of Consumer Marketing, Vol. 25 Iss: 5, pp.281 - 293

Sevil. Z. (2011) "A Theoretical Approach to Concept of Green Marketing". Interdisciplinary Journal of Contemporary Research in Business, vol.3, no. 2, pp.18081804.

Synovate (2011). "Synovate Survey Reveals Latest Green Habits And Consumption Across The World". http://www.marketresearchworld.net/content/view/3966/77/ 
Vazquez, R., Del Rio, A.B. and Iglesias, V. (2002).

"Consumer-based brand equity: development and validation of a measurement instrument", Journal of Marketing Management, 18, 27-49.

Veloutsou, Cleopatra, Christodoulides, George and de Chernatony, Leslie. (2013) "A Taxonomy of Measures for Consumer-Based Brand Equity: Drawing on the views of Managers in Europe". Journal of Product \& Brand

Management. 22, (24.5.), 238-248
Yoo, B., Donthu, N. and Lee, S. (2000) "An examination of selected marketing mix elements and brand equity", Journal of the Academy of Marketing Science, 28, (2), 195-211.

Zeithaml, V. A. (1988), "Consumer perceptions of price, quality and value: a means-end model and synthesis of evidence". Journal of Marketing, 52, 2-22. 